\title{
Experimental Study on the Treatment of the Urban Waste Leachates by Oxidation and Adsorption
}

\author{
H. Zouaghi ${ }^{1 *}$, M. Ruiti ${ }^{2}$ and B. Ben Thayer ${ }^{3}$ \\ ${ }^{1}$ National Engineering School of Monastir, Avenue Ibn El Jazzar, 5019, Monastir, Tunisia \\ ${ }^{2}$ National Agronomy Institute of Tunis, 43 Avenue Charles Nicolle, 1082, Tunis, Tunisia \\ ${ }^{3}$ High Institute of Rural Engineering and Equipment Medjez El Bab, Laboratory of Chemistry \\ and water quality, 9070, Medjez El Bab, Beja, Tunisia \\ *Corresponding author
}

\begin{tabular}{|c|c|}
\hline & A B S T R A C T \\
\hline & \multirow{6}{*}{$\begin{array}{l}\text { The present work deals with the leachate treatment using the following processes: } \\
\text { oxidation by the bleach. This treatment is preceded by a precipitation using } \\
\text { NaOH. The adsorption by bark Alep pine powder and fibers of date palm leaves is } \\
\text { used in the second part of the work. Monitoring of physicochemical parameters of } \\
\text { that leachate gave a pH of } 8.46 \text {; an electrical conductivity of } 18.24 \mathrm{mS} / \mathrm{cm} \text {, an } \\
\text { orthophosphate concentration of } 0.35 \mathrm{mg} / 1 \text {, an oxidability of } 125 \mathrm{mg} \mathrm{O}_{2} / 1 \text { and a } \\
\text { turbidity of } 252 \mathrm{FAU} \text {. Pretreatment with precipitation was considered. The aim is } \\
\text { to reduce the pollution in the leachate. Then, oxidation tests reduce the leachate } \\
\text { turbidity to } 48 \mathrm{FAU} \text {, as a dose of the bleach of } 0.29 \mathrm{~g} / \mathrm{l} \text {. Using adsorption for } \\
\text { leachate treatment requires the least investment cost. Adsorption with } 2 \mathrm{~g} \text { of Alep } \\
\text { pine bark } / 100 \mathrm{ml} \text { of leachate gave the best results of turbidity. However, an } \\
\text { additional treatment is required to reduce turbidity as minimum as possible. }\end{array}$} \\
\hline Keywords & \\
\hline $\begin{array}{l}\text { Leachate, } \\
\text { Oxidation, Bleach, } \\
\text { Adsorption, } \\
\text { Turbidity. }\end{array}$ & \\
\hline Article Info & \\
\hline $\begin{array}{l}\text { Accepted: } \\
\text { 28 October } 2017 \\
\text { Available Online: } \\
\text { 10 December } 2017\end{array}$ & \\
\hline & \\
\hline
\end{tabular}

\section{Introduction}

The increase in population, nowadays, has increased the potential of waste, especially urban waste. The most commonly used method for the treatment of this waste is landfilling. The biggest problem consists of the liquid effluent which goes from the wastes called leachate. It's collected in the big lagoon. However, it's polluted and harmful to the environment. Many studies are focused on the leachate treatment. Some treatment methods are chemical and others are biological. Precipitation is generally used for the removal of phosphate and heavy metals.
Heavy metals are generally precipitated as hydroxides by the addition of soda or lime. For the treatment of leachates, chemical precipitation is mainly used to remove insolubilization of one or more mineral compounds such as hardness $\left(\mathrm{Ca}^{2+}\right.$ and $\left.\mathrm{Mg}^{2+}\right)$, metals, certain anions such as $\mathrm{SO}_{4}{ }^{2-}, \mathrm{PO}_{4}{ }^{3-}$, $\mathrm{Fe}^{-}$.

Chemical precipitation can be carried out by various compounds such as lime or by very insoluble salts such as $\mathrm{AlPO}_{4}$ and $\mathrm{FePO}_{4}$ which precipitate in a colloidal state (1). In 
addition, the use of lime as a pre-treatment step for biologically stabilized leachate.

In addition, the use of lime as a pre-treatment step for biologically stabilized leachate reduces leachate salinity by $20-40 \%$ by decarbonating the effluent and precipitating $\mathrm{Ca}^{2+}$ and $\mathrm{Mg}^{2+}$, and eliminating (2) and (3), and the COD was $20-30 \%$ due to the coprecipitation of the organic macromolecules responsible for the clogging of humic acids.

Chemical precipitation may be slowed down or blocked by certain compounds present in the leachate. This is a spontaneous inhibition which can be avoided by the addition of induced inhibitors. The choice of the latter depends on the compound to be precipitated (1).

Chemical oxidation is widely studied for the treatment of effluents containing refractory materials such as leachate. Increasing interest has been shown in advanced oxidation processes.

Most of them, except simple ozonation $\left(\mathrm{O}_{3}\right)$, use a combination of strong oxidants, for example, $\mathrm{H}_{2} \mathrm{O}_{2}$ and $\mathrm{O}_{3}$, irradiation, ultraviolet (UV), ultrasound (US) or electron beam, and catalysts, for example, transition metal or photo-catalysis ions (4).

The disadvantages of the advanced oxidation process are the high demand for electrical energy for appliances such as ozone generators, UV lamps, and ultrasound, resulting in relatively high processing costs (5).

Salah (6) reported in his study that, once $1 \%$ $\mathrm{HClO}$ was added, the COD removal efficiency exceeded $80 \%$ and then became stable for the other percentages. The addition of bleach removes organic matter in a significant way from $20 \%$ by exceeding $50 \%$ of the COD eliminated.
Adsorption is an applied method for the removal of non-biodegradable organic compounds (7) but not for $\mathrm{NH}_{3}$ (8). It is a physical phenomenon for fixing molecules on the surface of a solid by means of Van Der Waals bonds (electrostatic type bonds of low intensity, with energies of interaction between 5 and $40 \mathrm{~kJ} / \mathrm{mol}$ ).

Adsorption can be considered in a simple manner, such as increasing the concentration of a substance at the solid-fluid interface (9).

Tanade et al., (10) show that porosity and pore diameter allow selection of the adsorbed molecule. Many materials have good natural properties which can be improved by suitable treatment, for example, but not limited to: wood sawdust, calcium aluminate, pulverized chalk, animal black, fly ash, metal oxide: bauxite, zirconium oxide, phosphate Calcium, silicas, silicates: bentonites, zeolites, attapulgite. These materials can be activated by calcination or chemical treatment (11). Adsorption plays an important role in selecting the most suitable and most economical adsorbent body for the desired result.

This work focuses the study of leachate treatment from Medjez El Bab landfill, a small town in the northwest of Tunisia. In the first part, a pretreatment using precipitation with soda is chosen. Then, oxidation tests are done using the bleach. In the second part, biological treatment by adsorption is used. Those tests are followed by oxidation tests. The aim is to limit the dose of the bleach.

\section{Materials and Methods}

Leachates are collected from the controlled landfill of Medjez El Bab, a small town of 20 thousand inhabitants, located in the northwest of Tunisia. Its characteristics are presented in Table 1. 
In relation to the Tunisian standard of rejection in the maritime public domain, this leachate isn't conformal. To be rejected, $\mathrm{pH}$ must be between 6.5 and 8.5. The Suspended matter shall not exceed $0.03 \mathrm{~g} / \mathrm{l}$ and the orthophosphates concentration of $0.001 \mathrm{mg} / \mathrm{l}$.

As regards the Tunisian standard for discharge in public canalization, $\mathrm{pH}$ has to be between 6.5 and 9. The Suspended matter hasn't overtaken $0.4 \mathrm{~g} / \mathrm{l}$ and the orthophosphates concentration has to be less than $0.01 \mathrm{mg} / \mathrm{l}$. So, Leachate needs to be treated.

\section{Measurement protocol}

The sample analyzes were carried out in the chemistry and water quality laboratory. The aim is to determine leachate physicochemical characteristics before and during treatment. It consists of determining $\mathrm{pH}$, electrical conductivity (CE), Suspended matter (SM), the dry residue (RS), Oxidability, determination of orthophosphates and turbidity.

The $\mathrm{pH}$-meter used is METTLER TOLEDO MP 220. It is calibrated using two buffer solutions $\left(\mathrm{pH}_{4}\right.$ and $\left.\mathrm{pH}_{7}\right)$.

The apparatus used for measuring the electrical conductivity is the conductivity meter WTW LF 521.

It is previously calibrated and the analysis is carried out in a beaker containing $50 \mathrm{ml}$ of water. This instrument measures conductivity in $\mathrm{mS} / \mathrm{cm}$ or $\mu \mathrm{S} / \mathrm{cm}$.

Suspended matter measurement follows this method:

Rinse a filter paper with distilled water to remove the starch and place it in the stove at $105^{\circ} \mathrm{C}$ until dry.
Insert the filter paper into the desiccators to cool and avoid moisture for $15 \mathrm{~min}$.

Weigh the mass $m_{0}$ of the filter paper.

After rinsing with distilled water, place it on the filtration unit and add a definite volume (V) of the sample.

Place the filter in the stove at $105^{\circ} \mathrm{C}$ until constant weight.

Weigh the filter paper and record its mass $m_{1}$.

The SM is given in this formula:

$S M(m g / l)=\frac{m_{1}-m_{0}}{V} \times 100$

The determination of the dry residue (DR) follows this procedure:

In a previously weighed beaker, introduce a water volume $\mathrm{V}$.

Evaporate gradually on a preheated plate. When the remaining amount becomes very low, transfer the beaker to the oven at $105^{\circ} \mathrm{C}$, wait for complete water evaporation.

Remove the beaker; allow it cooling in the desiccator and weigh.

The DR takes this form:

$$
D R(m g / l)=\frac{P_{1}-P_{0}}{V} \times 100
$$

The oxidability is determined to evaluate the polluting load of waste water. The measurement of oxidability using potassium permanganate consists of oxidizing organic materials oxidable by $\mathrm{KMnO}_{4}$ at warm.

It consists of introducing successively into 2 Erlenmeyers the following quantities: 
Erlenmeyer 1 of $250 \mathrm{ml}$ :

$100 \mathrm{ml}$ of water;

$10 \mathrm{ml}$ of saturated $\mathrm{NaHCO}_{3}$ solution;

$10 \mathrm{ml}$ of $\mathrm{KMnO}_{4}$ solution, $\mathrm{N} / 80$.

Erlenmeyer 2 of 500ml:

$200 \mathrm{ml}$ of water;

$20 \mathrm{ml}$ of saturated $\mathrm{NaHCO}_{3}$ solution;

$20 \mathrm{ml}$ of $\mathrm{KMnO}_{4}$ solution, N/80.

Bring the 2 containers to ebullition; boil 10 minutes from the moment when the bubbles come to puncture the liquid surface.

Allow to cool during 30min in air stream;

Add $10 \mathrm{ml}$ of $\mathrm{H}_{2} \mathrm{SO}_{4}(50 \%)$ in Erlenmeyer 1 and $20 \mathrm{ml}$ in Erlenmeyer 2;

Add $10 \mathrm{ml}$ of Mohr salt to each Erlenmeyer until obtaining a total discoloration (shake if necessary);

Let cool again;

Return to the weak but persistent pink tint by introducing the solution of potassium permanganate $\mathrm{N} / 80$ with a graduated burette.

The difference $\mathrm{V}$ between $\mathrm{V}_{2}$ and $\mathrm{V}_{1}$ of $\mathrm{KMnO}_{4}$ (N/80) measured during two titrations, represents the amount of $\mathrm{KMnO}_{4}$ used to oxidize the organic matter in $100 \mathrm{ml}$ of water to be analyzed. By convention, it also corresponds to the number of milligrams of oxygen consumed, per liter of water, for this oxidation.

To determine the phosphorus concentration, the orthophosphate assay method is used. However, it's necessary to establish the calibration curve which gives the phosphorus concentration as function of the absorbance. The aim is to determine the different forms of phosphates contained in leachate. It can be classified as orthophosphates which indicate the presence of fertilizers or polyphosphates proof of detergents or other organic compounds.

The procedure is as follows:

Introduce $20 \mathrm{ml}$ of water into a $25 \mathrm{ml}$ flask;

Add $1 \mathrm{ml}$ of ascorbic acid and shake;

Add $4 \mathrm{ml}$ of combined reagent (which is obtained by mixing $50 \mathrm{ml}$ of $5 \mathrm{~N}, \mathrm{H}_{2} \mathrm{SO}_{4}, 5 \mathrm{ml}$ of tartrate and $15 \mathrm{ml}$ of molybdate) and stirring;

Wait 30min until the appearance of a blue color;

Perform a spectrophotometer reading at a wavelength of $880 \mathrm{~nm}$;

Refer to the calibration curve to evaluate reading in orthophosphates.

The turbidity measurement of leachate comes within the framework of the development of a possible clarification treatment, after treatment to check for proper operation.

Turbidity is measured with a $\mathrm{HACH}$ DR/4000U spectrophotometer. The unit of measurement of the turbidity used is the FAU (Formazine Attenuation Unit) at a wavelength $\lambda=860 \mathrm{~nm}$.

\section{Leachate treatment by oxidation using the bleach}

The leachate treatment by oxidation is a common method used in the bibliography (45-6). The choice of the oxidant depends on the availability and the cost. The chosen oxidant is the bleach having the characteristics shown in Table 2. 
A $200 \mathrm{ml}$ Erlenmeyers is used with a $100 \mathrm{ml}$ of leachate.

The study of the oxidation of the leachates is carried out with commercial bleach at $12^{\circ}$ of chlorine. By opening the bleach bottle, the product loses its chlorometric degree which is determined by the iodometry method. This method consists of:

Preparation of a diluted bleach solution of 25 times named $\mathrm{S}_{1}$.

$2 \mathrm{ml}$ of $\mathrm{S}_{1}+20 \mathrm{ml}$ of distilled water $+1 \mathrm{ml}$ of glacial acetic acid $+1 / 4$ pinch of potassium iodide $\mathrm{KI}$ in a $200 \mathrm{ml}$ Erlenmeyer flask;

Shake until a red color appears;

Add $0,1 \mathrm{~N}$ of sodium thiosulfate dropwise until a yellow color is obtained;

Continue adding dropwise $0,1 \mathrm{~N}$ of sodium thiosulfate until the color yellow disappears (colorless).

Note the volume $\mathrm{V}$ : total volume of thiosulfate of sodium $0.1 \mathrm{~N}$ poured.

Degree of chlorometry $=V \times 0,112 \times 25$

The degree of chlorometry is determined for each test.

The technique of the request in chlorine consists of:

In 6 Erlenmeyers of $200 \mathrm{ml}$, introduce $100 \mathrm{ml}$ of leachate and increasing quantities of the bleach with an interval of $10 \mathrm{ml}$. The solutions were agitated with a magnetic stirrer, at a stirring speed of 100rpm, during 20min. The samples are sitting for half an hour, and then the various physicochemical parameters are measured.
The minimum turbidity corresponds to a determined dose of bleach. From this volume, the same procedure is repeated by restricting the volume corresponding to the minimum turbidity with a $2 \mathrm{ml}$ interval.

After determining the minimum of turbidity, the same tests are repeated for an interval of $0,5 \mathrm{ml}$ of the bleach volume.

Once the minimum of turbidity is determined, corresponding bleach volumes are then translated into doses. Knowing the degree of chlorometry, the bleach concentration is:

1 degree of chlorometry $=3,17 \mathrm{gCl}_{2} /$ l of the bleach

\section{Leachate pre-treatment}

In order to minimize the bleach doses, corresponding to the minimum turbidity, the leachate is pretreated. This method objective is to improve the quality of the leachate before oxidation treatment.

The principle consists in adding defined doses of a chosen base and measuring the $\mathrm{pH}$ per dose introduced. The $\mathrm{pH}$ is set at 8,5; 9; 9,5; 10 and 10,5 per liter of leachate. Once the $\mathrm{pH}$ is set, the solution is standing until decanting and oxidation tests began.

The pretreatment used is chemical precipitation by various bases, caustic soda which characteristics are presented in Table 3.

\section{Biological treatment: Adsorption}

The leachate treatment by adsorption is the least costly and most suitable method of product availability. But, it remains the choice of the best adsorbent. In a first step, the stirring time was set at $2 \mathrm{~h}$ and the stirring speed was set at $300 \mathrm{rpm}$. 
In 5 Erlenmeyers, $100 \mathrm{ml}$ of leachate and increasing quantities of adsorbent $(2,4,6,8$ and $10 \mathrm{~g}$ ) were introduced. Agitation is carried out for $2 \mathrm{~h}$ using a magnetic bar and stirrer of AGIMATIC-S type. Samples are allowed to stand for $1 / 2 \mathrm{~h}$. Filtration of each sample is then carried out using filter paper previously washed with distilled water.

Adsorbents used are date palm leaves and Aleppo pine bark. The activated charcoal is used as a reference.

\section{Adsorbents preparation}

The palm leaves and the pine bark of Alep are cut, well washed with tap and distilled water in order to remove impurities. They are then dried in the stove for $2 \mathrm{~h}$ at $105^{\circ} \mathrm{C}$. The final step consists of crushing. The adsorbent takes the form presented in Figure 1.

For every adsorbent quantity, stirring time varies $(10,20,30,60$ and 120min). The tracking parameters are determined.

\section{Results and Discussion}

Two treatment methods are tested in this part. The first one is a chemical method. Leachates are pretreated by precipitation with the soda followed by oxidation with the bleach.

The second method consists of using a biological treatment by adsorption. The aim is to compare between the different treatments methods with the minimum of doses.

\section{Leachate treated with oxidation with the Bleach}

Before beginning the oxidation tests, it's necessary to determine the break point.

The break point determination of the leachates consists of plotting the $\mathrm{pH}$ curve as a function of the chlorine introduced and thus determining the minimum of $\mathrm{pH}$. This value corresponds to the break point. The results are presented in Figure 2.

It shows that the higher the initial $\mathrm{pH}$, the greater the dose of bleach. For a precipitation at $\mathrm{pH}=8.6$; the break point is at a $\mathrm{pH}$ of 8.1; whereas for a precipitation at $\mathrm{pH}=10.5$, it's at a $\mathrm{pH}$ of 9.57. However, the dose corresponding to the point break is reached increases; It goes from 0.16 to $0.43 \mathrm{~g} / \mathrm{l}$ for the same example.

Salah (6) worked on the leachate treating by oxidation using the bleach. His study showed that the presence of the bleach in a large quantity slightly increases the $\mathrm{pH}$. The latter varies between 7,5 and 8 for doses of bleach between 0,38 and $19,02 \mathrm{~g} / \mathrm{l}$ of $\mathrm{Cl}_{2}$.

The variation of the turbidity as a function of the bleach dose is presented in Figure 3.

The turbidity variation curve decreases and then increases as the function of the bleach dose. This indicates that the liquid has different effects on turbidity.

For precipitation at $\mathrm{pH}=10.5$, the turbidity increases and then decreases to a minimum of 48FAU corresponding to a bleach dose of $0,29 \mathrm{~g} / \mathrm{l}$ and then a further increase.

Salah (6) conducted oxidation tests using bleach, on leachates having an initial turbidity of 6170FAU. Results indicate that oxidation with chlorine produces a foam which can be attributed to the release of $\mathrm{Cl}_{2}$ by removing colloidal matter. This reduction results in a decrease in leachate turbidity.

From a dose of $0,076 \mathrm{~g} / \mathrm{l}$ of the bleach, the reduction in turbidity is $45 \%$ whereas it becomes more remarkable from $3,8 \mathrm{~g} / 1$ of $\mathrm{Cl}_{2}$. The reduction of turbidity tends towards $100 \%$ as soon as the dose exceeds $13,31 \mathrm{~g} / \mathrm{l}$. 
Salah (6) also adds that after precipitation with soda at $\mathrm{pH}=11$, the leachate becomes less loaded. After adding bleach, the leachate becomes more and clearer, whenever it needs higher doses. From a bleach concentration of $5.71 \mathrm{~g} / 1$, the turbidity yield is $99.66 \%$.

The oxidability curve as a function of the bleach dose is presented in Figure 4. The oxidability decreases as a function of the dose of bleach introduced. For the oxidation of raw leachate, it decreases from 13.5 to $3 \mathrm{mg} \mathrm{O}_{2} / 1$ for a bleach dose between 0.06 and $2.41 \mathrm{~g} / \mathrm{l}$.

Whereas, after precipitation with soda, for a $\mathrm{pH}=8,5$, it decreases from 13 to $6 \mathrm{mg} \mathrm{O}_{2} / 1$ for a bleach dose between 0,06 and $1,44 \mathrm{~g} / 1$. Compared with precipitation at $\mathrm{pH}=10,5$, it decreases from 10.5 to $3 \mathrm{mg} \mathrm{O}_{2} / \mathrm{l}$ for the bleach dose of between 0.22 and $1.8 \mathrm{~g} / \mathrm{l}$. These results indicate that the greater the precipitation, the lower is the oxidability. Thus, soda removes a large amount of organic matter and the oxidation by bleach eliminates further.

Other oxidants can be used and which provide good treatment results such as ozone $\left(\mathrm{O}_{3}\right)$. However, this oxidant has a high cost, instant manufacturing and requires a long administrative procedure in order to be put into operation.

There is also another oxidizer that we have tried to use, which is $\mathrm{H}_{2} \mathrm{O}_{2}$ known as hydrogen peroxide. However, this oxidizer is not available for public use despite its relatively low cost. In addition, the administrative procedure for recovering the product is quite complicated.

\section{Leachate treated with adsorption process}

This part concerns the adsorption of the leachate by different adsorbents. The goal is to find the adsorbent to reduce the turbidity.
Several adsorbents have been used to determine which one will allow for minimum turbidity. Quantities from 2 to $10 \mathrm{~g}$ of each adsorbent are used. Several stirring times are tested. The raw leachate has an initial turbidity of 252FAU. The selected adsorbents are $4 \mathrm{~g}$ of date palm leaves which give a turbidity of 140FAU and $2 \mathrm{~g}$ of Alep pine bark powder, the adsorption of which gives a turbidity of 93FAU. Activated carbon is used as a reference adsorbent.

The activated carbon in powder form (CAP) or in grain (GAC) has been used successfully in many leachates treatments for factories and drinking water to remove the taste and smell (12-13-14-15). Numerous studies indicate that CAP is not as effective as GAC, but its use is less costly. In fact, as shown by Fiessinger et al., (14), when the required CAP dose exceeds $20 \mathrm{mg} / \mathrm{l}$, it is preferable to use CAG filtration with contact times between 5 and 30min (Fig. 5).

Activated carbon adsorption has been used with biological treatment for effective leachate treatment (16-17-18). The nonbiodegradable organic materials, COD, and color can be reduced to acceptable levels. Rodriguez et al., (19) investigated the effectiveness of CAP and the various resins in reducing non-biodegradable organic matter. The activated carbon showed a strong adsorption capacity of $85 \%$ of the COD.

After several tests for leachate treatment, the minimum turbidity corresponds to the palm dates leaves and the Alep pine bark. The variation of leachate characteristics for the two adsorbents is presented in Figure 6.

Choosing the date-palm leaves and pine bark Alep with specific quantities, the variation of the parameters of leachate are determined. The results are different from one parameter to another. 
Fig.1 Adsorbent form before and after preparation

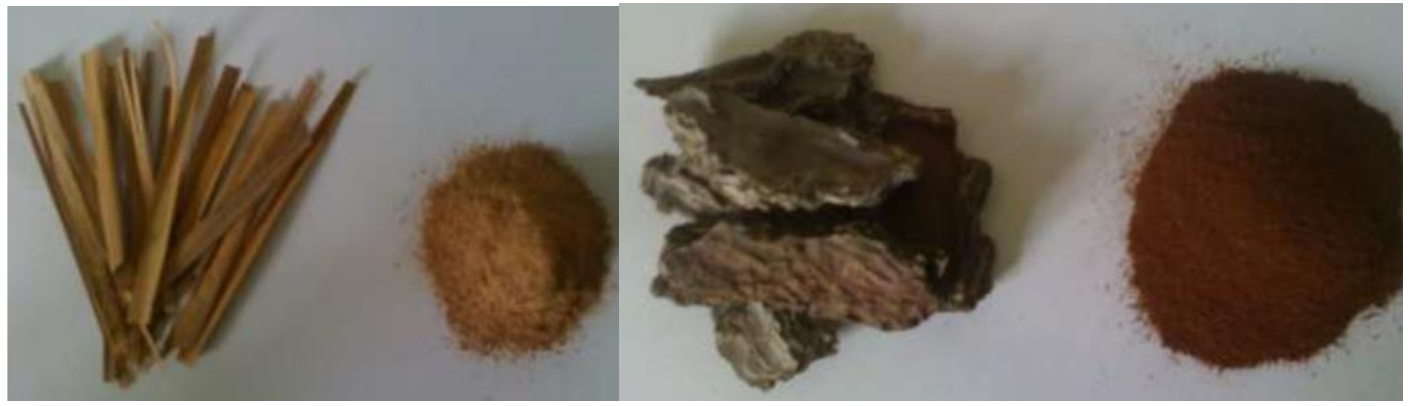

Fig.2 Determination of leachate break point before and after precipitation with soda
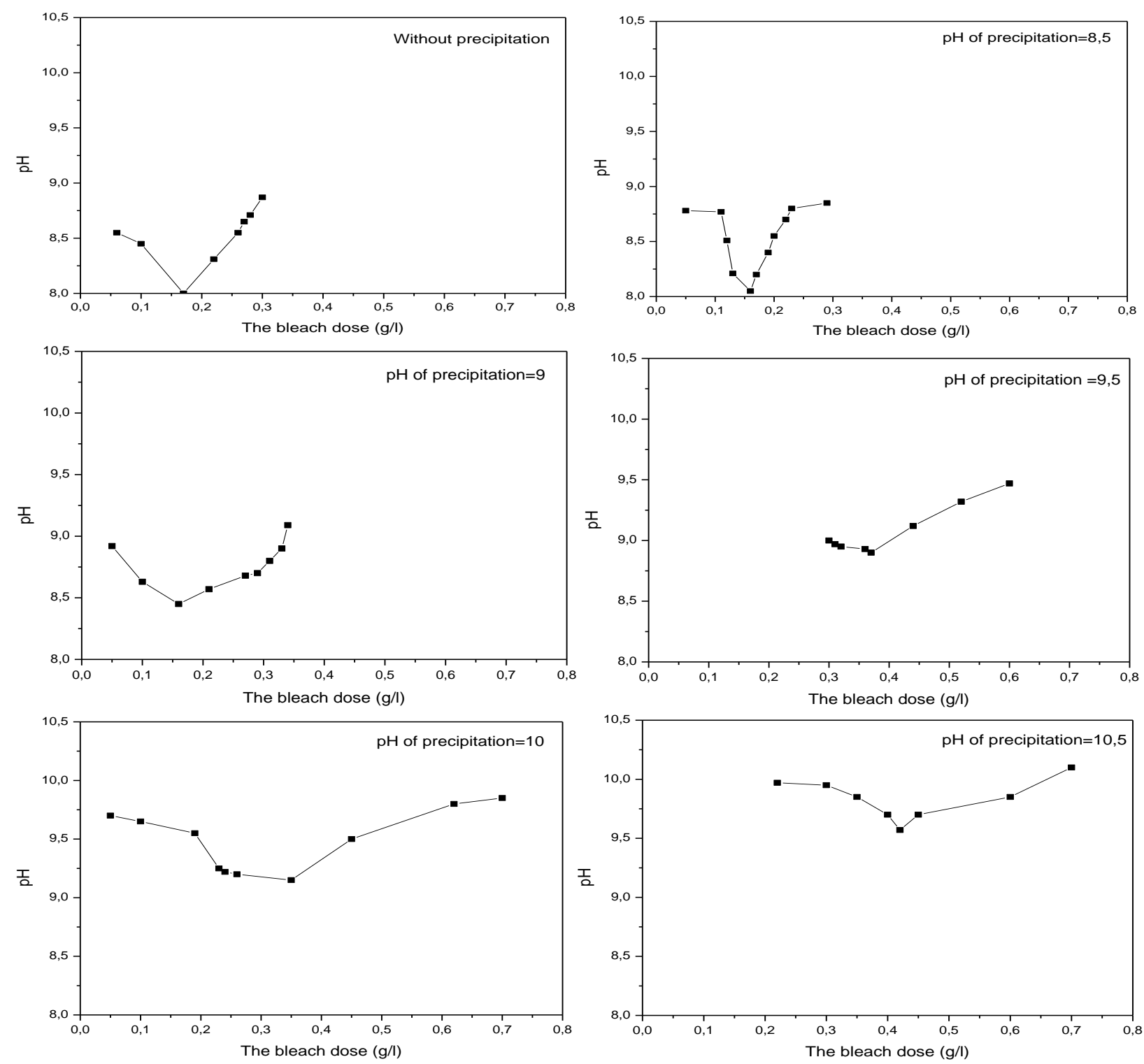
Fig.3 Turbidity variation as function of the bleach dose
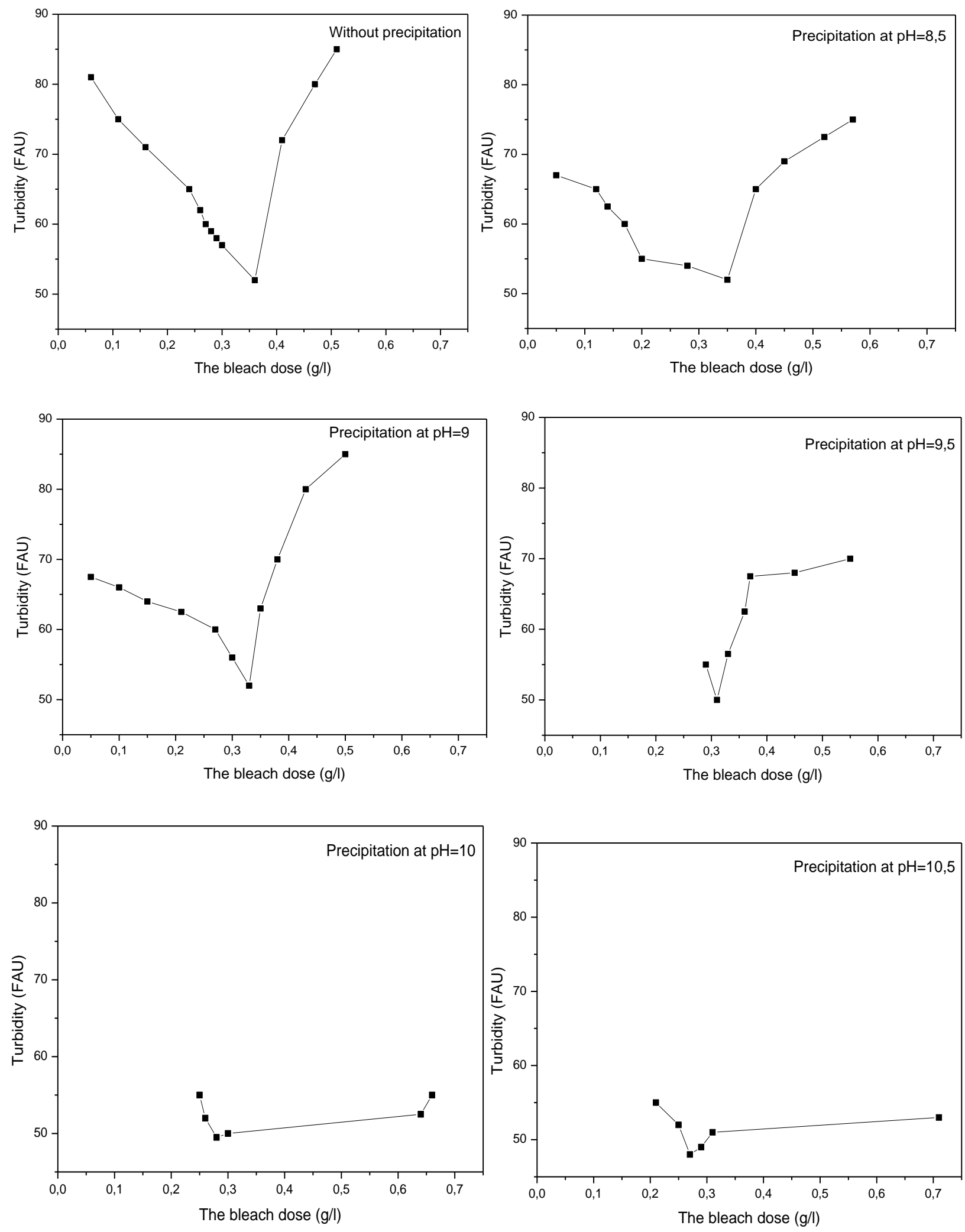
Fig.4 Oxidability as function of the bleach dose
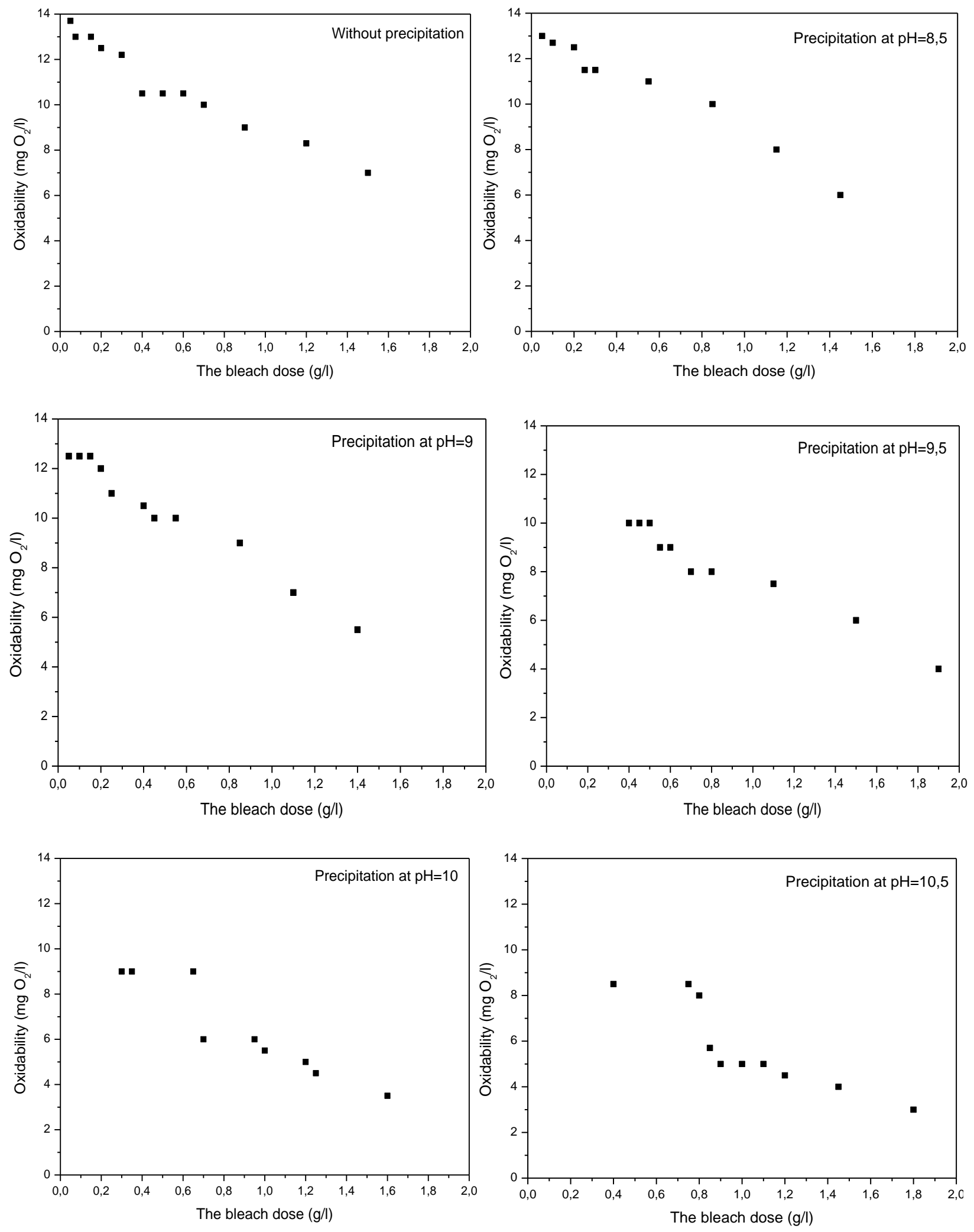
Fig.5 Characteristics of leachates treated by adsorption with activated carbon
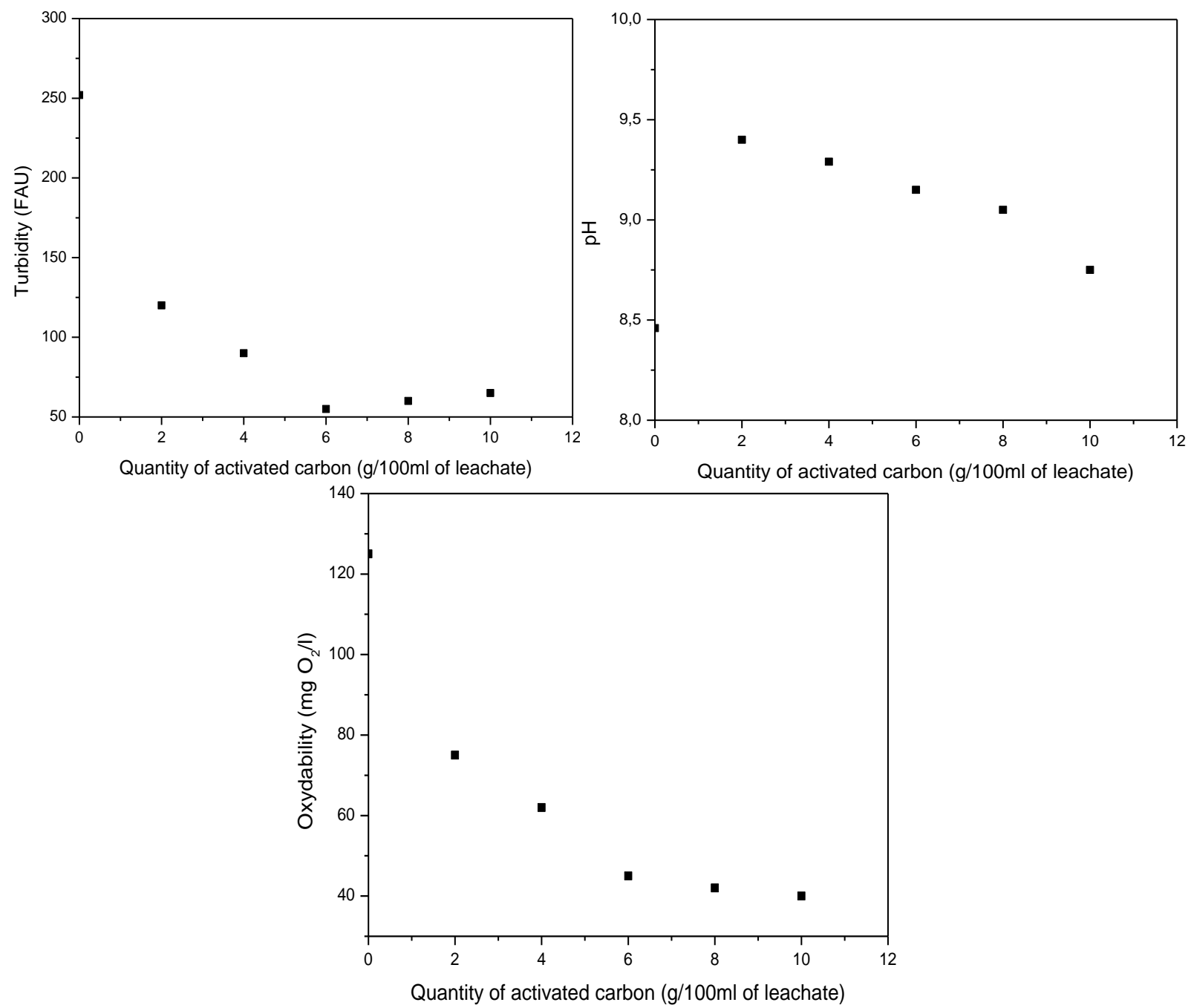

Fig.6 Leachates characteristics during its treatment using adsorption
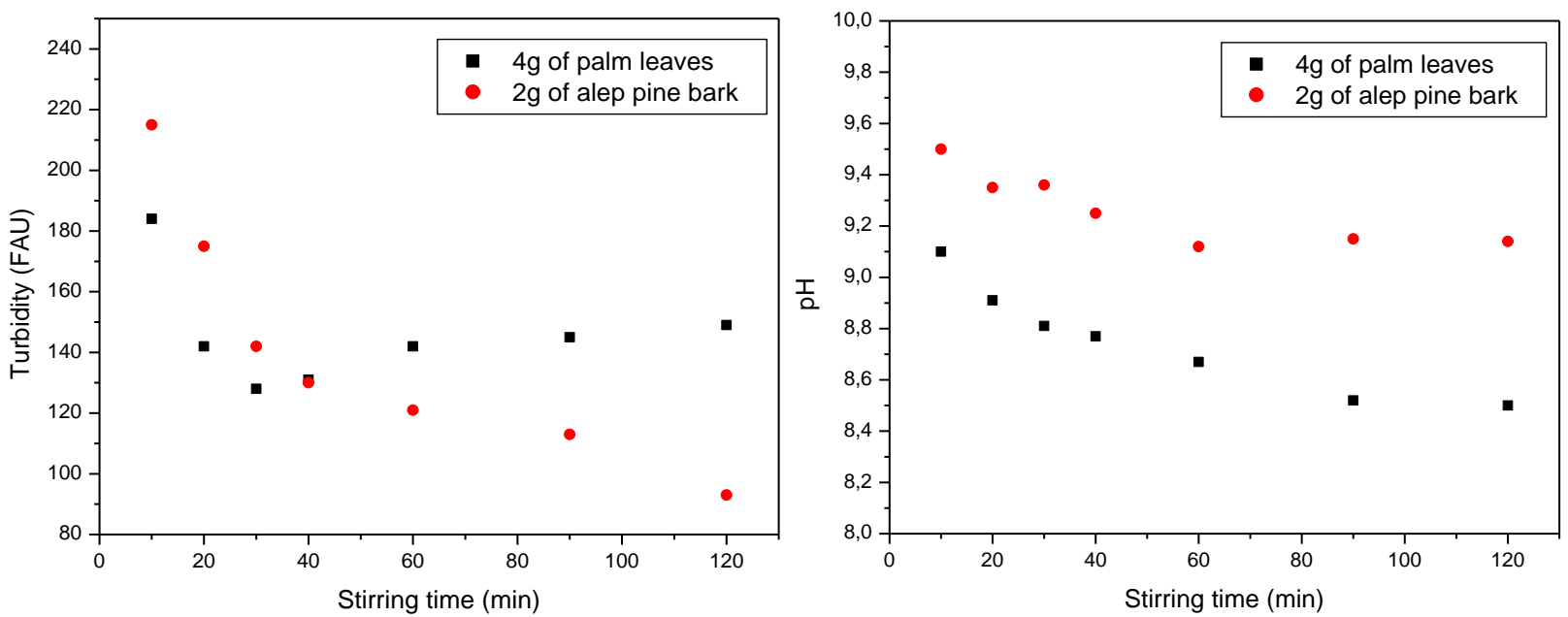


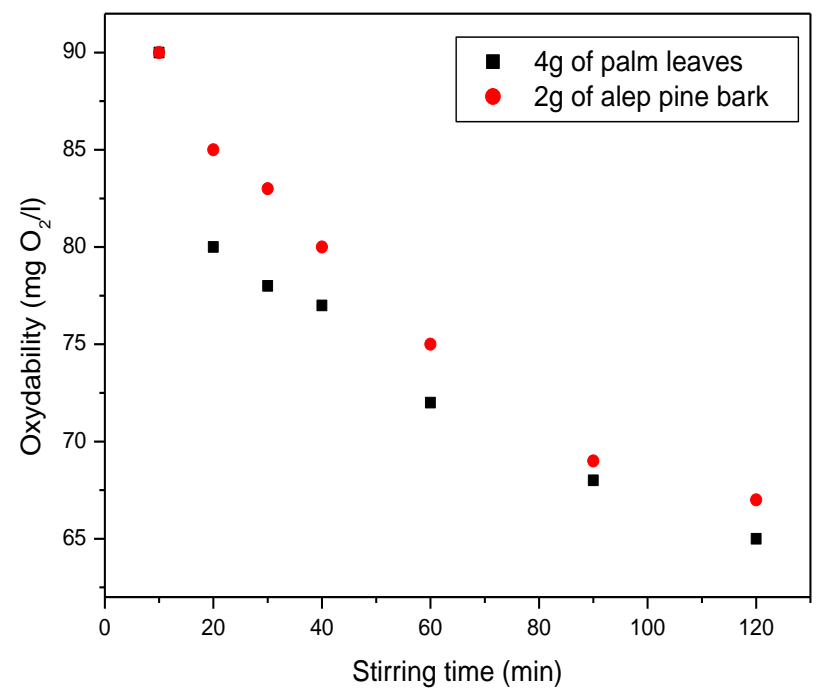

Fig.7 Leachate characteristics treated by adsorption and oxidation with the bleach
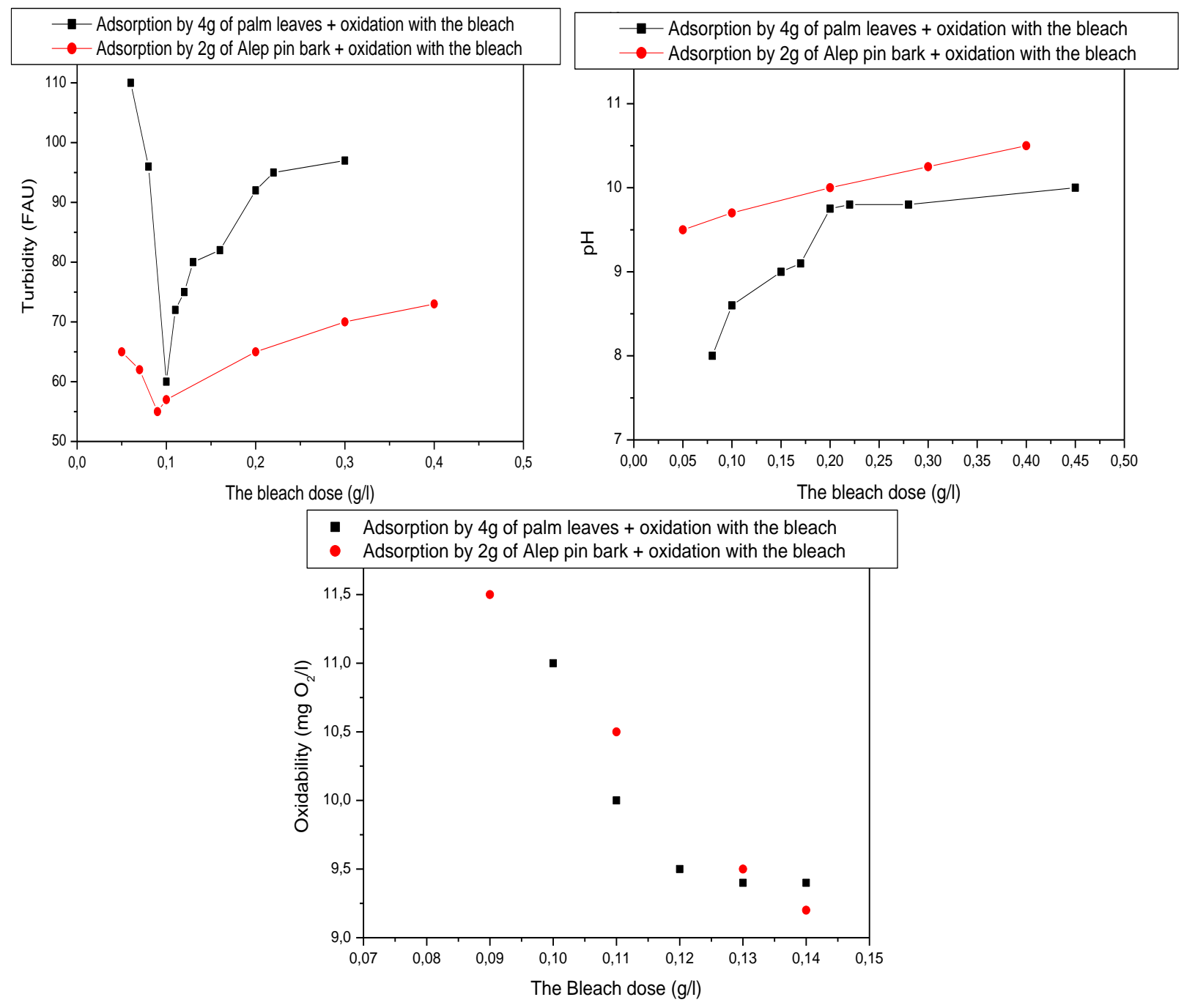
Table.1 Leachate characteristics

\begin{tabular}{|c|c|c|}
\hline Designation & Unit & Value \\
\hline $\mathrm{pH}$ & - & 8,46 \\
\hline electrical conductivity & $\mathrm{mS} / \mathrm{cm}$ & 18,24 \\
\hline Salinity & $\mathrm{g} / \mathrm{l}$ & 12,55 \\
\hline Dry residue & $\mathrm{g} / \mathrm{l}$ & 21,88 \\
\hline Suspended matter & $\mathrm{g} / \mathrm{l}$ & 12,3 \\
\hline Orthophosphates concentration & $\mathrm{mg} / \mathrm{l}$ & 0,35 \\
\hline Oxidability & $\mathrm{mg} \mathrm{O}_{2} / 1$ & 125 \\
\hline Color & - & Dark brown \\
\hline Smell & - & bad \\
\hline Turbidity & FAU & 252 \\
\hline
\end{tabular}

Table. 2 Characteristics of used oxidant

\begin{tabular}{|c|c|c|c|c|c|}
\hline Designation & $\begin{array}{c}\text { Molar } \\
\text { mass }\end{array}$ & Use & $\begin{array}{c}\text { Available } \\
\text { shape }\end{array}$ & $\begin{array}{c}\text { Used mother } \\
\text { solution }\end{array}$ & Notes \\
\hline $\begin{array}{l}\text { Sodium hypochlorite } \\
\text { NaClO (The bleach) }\end{array}$ & 74.5 & Disinfection & $\begin{array}{c}\text { Yellow } \\
\text { liquid }\end{array}$ & $\begin{array}{c}5 \text { to } 12^{\circ} \\
\text { chlorometric }\end{array}$ & $\begin{array}{l}\text { Basic oxidizing agent. } \\
\text { Unstable solution }\end{array}$ \\
\hline
\end{tabular}

Table.3 Characteristics of bases used for chemical precipitation of leachates

\begin{tabular}{|c|c|c|c|c|}
\hline Designation & Molar mass & Used form & Mother solution & Notes \\
\hline Caustic soda $\mathrm{NaOH}$ & 40 & Solid in flakes & $0.1 \mathrm{~N}$ & Dangerous corrosive \\
\hline
\end{tabular}

Table.4 Tracking parameters of treated leachate using adsorption

\begin{tabular}{|c|c|c|c|}
\hline Adsorbent type & Palm leaves & Alep pine bark & Activated carbon \\
\hline Adsorbent quantity $(\mathrm{g})$ & 4 & 2 & 6 \\
\hline Stirring time $(\mathrm{min})$ & 30 & 120 & 120 \\
\hline $\mathrm{pH}$ & 8.81 & 9.14 & 9.40 \\
\hline Conductivity $(\mathrm{mS} / \mathrm{cm})$ & 9.52 & 9.60 & 9.71 \\
\hline $\mathrm{PO}_{4}^{3-}$ concentration $(\mathrm{mg} / \mathrm{l})$ & 0.75 & 0.50 & 0 \\
\hline Oxidability $(\mathrm{mg} \mathrm{O} / \mathrm{l})$ & 82 & 67 & 45 \\
\hline Turbidity $(\mathrm{FAU})$ & 128 & 93 & 53 \\
\hline
\end{tabular}

Table.5 Comparison between final treated leachate

\begin{tabular}{|c|c|c|}
\hline Adsorbent & Alep pine bark & Palm leaves \\
\hline The bleach dose (g/l) & 0.087 & 0.103 \\
\hline $\mathbf{p H}$ & 9.65 & 8.57 \\
\hline Orthophosphates concentration (mg/l) & 0 & 0 \\
\hline Oxidability (mg O $/ \mathbf{l})$ & 11.5 & 11 \\
\hline Turbidity (FAU) & 55 & 61 \\
\hline
\end{tabular}


Note that the optimum of turbidity is for an adsorption using the pine bark of Alep after a stirring time of $120 \mathrm{~min}$. For this adsorbent, the turbidity decreases even after $120 \mathrm{~min}$ of stirring. For the date palm leaves, the minimum turbidity is $128 \mathrm{FAU}$ for a stirring time of $30 \mathrm{~min}$.

For $\mathrm{pH}$ and electrical conductivity, these parameters decrease for both adsorbents. However, the use of date palm leaves has a considerable decrease compared to the other adsorbent.

It's seen that the adsorbents used contain phosphorus. Then, it's better to use palm leaves which give a concentration of $0,45 \mathrm{mg} / 1$ after a stirring time of $120 \mathrm{~min}$ compared to $0.5 \mathrm{mg} / \mathrm{l}$ using the bark for the same stirring time. Table 4 summarizes the tracking parameters leachate for minimum turbidity.

The final solution has a high turbidity compared to that treated by oxidation with bleach. Additional treatment is considered. The oxidation treatment is chosen. The aim is to minimize the bleach doses for a minimum turbidity. The results are presented in Figure 7.

The oxidability variation as a function of the bleach dose is a decreasing curve. For leachate treated with Alep pin bark, it goes from 11,5 to 8 for the bleach doses between 0,09 and $0,17 \mathrm{~g} / \mathrm{l}$. The minimum turbidity corresponds to an oxidability of $11.5 \mathrm{mg} \mathrm{O}_{2} / 1$. The $\mathrm{pH}$ variation curve increases as a function of the bleach dose. Values range from 9.62 to 11.71 for chlorine doses between 0.07 and $0.7 \mathrm{~g} / \mathrm{l}$. The minimum turbidity is about $\mathrm{pH}=$ 9.67. The minimum of turbidity is about 55FAU for leachate treated by adsorption with Alep pin bark and oxidation with the bleach.

The oxidation with bleach after adsorption with Alep pine bark powder is carried out with minimal bleach doses in relation to the oxidation of the raw leachate. This dose decreases from 0.35 to $0.087 \mathrm{~g} / \mathrm{l}$ for a turbidity of 53 and 55 FAU (close turbidity value).

The change in turbidity and oxidability after leachate treatment by adsorption with powdered Alep pine bark followed by oxidation with bleach indicated a decrease in turbidity from 252 to 55FAU and of 125 to $11.5 \mathrm{mg} \mathrm{O}_{2} / 1$ for oxidability. Compared with palm leaves, the final turbidity is about $61 \mathrm{FAU}$ and the oxidability is about $11 \mathrm{mg}$ $\mathrm{O}_{2} / \mathrm{l}$ (Table 5).

This work is about with the leachate treatment from Medjez El Bab landfill, a small town in the northwest of Tunisia. The raw leachate is characterized by a turbidity of 252FAU, a pH $=8.46$ and an oxidability of $125 \mathrm{mg} \mathrm{O}_{2} / 1$.

Initially, the leachate was precipitated with soda. The aim is to reduce the leachate load. This treatment was followed by oxidation with the bleach.

The treated leachate corresponds to that having the lowest turbidity; it is about 48 FAU, for the bleach dose of $0.29 \mathrm{~g} / \mathrm{l}$ and a precipitation at a $\mathrm{pH}$ of 10.5 .

In a second step, the leachate was treated by adsorption. It is a question of using a biological treatment that does not harm the environment. Several tests have been carried out on a multitude of adsorbents. By selecting date palm leaves and Alep pine bark in welldetermined quantities, the variation of leachate monitoring parameters was determined.

The variation of turbidity over time indicates that Aleppo pine bark gives better results. After 30 min of stirring, the final turbidity is about 93 FAU compared with the palm leaves giving a minimum turbidity of about 128 FAU after 30 min of agitation. 
The adsorption treatment of leachates is not sufficient to have better quality (turbidity in discharge standards in the National Office of sanitation "ONAS" or in the maritime public domain). So, additional treatment is necessary.

For adsorption with fiber date palm leaves, and oxidation with bleach, as a complementary to adsorption, the final turbidity is 61FAU. With regard to the adsorption with Alep pine bark in powder and oxidation with bleach, the final turbidity is 55FAU. This treatment gives better turbidity results with minimal bleach doses compared to the treatment of the raw leachate and that the final solution has similar physicochemical properties.

The choice of the best adsorbent is that which gives minimal turbidity with minimal doses. For the oxidation treatment, we choose the Alep pine bark which gives better turbidity with lower bleach doses $(0,08 \mathrm{~g} / \mathrm{l}$ compared to $0,103 \mathrm{~g} / \mathrm{l}$ of bleach after adsorption with palm leaves).

\section{Acknowledgement}

This work was performed in the laboratory of chemistry and water quality of the higher engineering school of the rural equipment of Medjez El Bab (ESIER) in Tunisia. It was carried out as part of a master's degree.

\section{References}

1. Cec EN F., Aktas O., (2001). Effect of PAC addition in combined treatment of landfill leachate and domestic wastewater in semi-continuously fed-batch and continuous-flow reactors, Water SA 27, pp: $177-188$.

2. Cec EN F., Aktas O., (2004). Aerobic cotreatment of landfill leachate with domestic wastewater, Environ. Eng. Sci. 21, pp: 303-312.

3. Fiessinger F. et Richard Y. (1975). La technologic du traitement des eaux potables par le charbon actif granul6. Techqs. Sci. Munic. 7, 271-273; 8-9, 339$351 ; 10,415-428$.

4. Gammie, L. and Giesbrecht, G. FullScale Operation of Granular Activated Carbon Contactors at Regina-Moose Jaw, Sas- katchewan. AWWA Ann. Conf., Denver, Colo., June 22-26, 1986.

5. Gomella. C, Guerree. H. (1978). Le traitement des eaux publiques industrielles et rivées. Deuxième édition, pp : $218-220$.

6. Graese SL, Snoeyink VL, Lee RG (1987). Granular activated carbon filteradsorber systems. Journal (American Water Works Association), Vol. 79, No. 12, Filtration (DECEMBER 1987), pp. 64-74.

7. HERZ O (1991). Odeurs et désodorisation dans l'environnement, pp. 185-190.

8. Korniawan. TA, Wai Hung. L, Gilbert. C. (2005). Physico - chemical treatment for removal of recalcitrant contaminants from landfill leachate, pp: 43 - 49 .

9. Korniawan. TA, Wai Hung. L, Gilbert. C. (2005). Physico - chemical treatment for removal of recalcitrant contaminants from landfill leachate, pp: 43 - 49

10. Lopez A, Pagano M, Volpe A, Di Pinto AC, (2004). Fenton's pre-treatment of mature landfill leachate. Chemosphere, 2004 - Elsevier. Volume 54, Issue 7, February 2004, Pages 1005-1010.

11. Morawe B., Ramteke D.S., Vogelpohl A., (1995). Activated carbon column performance studies of biologically treated landfill leachate, Chem. Eng. Process. 34, pp : 299-303.

12. Rodriguez J., Castrillon L., Maranon E., Sastre H., Fernandez E., (2004). Removal of non-biodegradable organic matter from 
landfill leachates by adsorption, Water Res. 38 pp: 3297-3303.

13. Rovel. JM. (2006). Memento technique de l'eau, tome 1 , deuxième édition, $\mathrm{pp}$ : 220-1050.

14. Salah. S. (2009). Contribution à l'étude de traitement des lixiviats chimiquement prétraités par un réacteur biologique à (Stipa tenacissima). Mémoire de mastère, pp: 167 - 169.

15. Slater C, Ahlert R., Uchrin C, (1983). Treatment of landfilll leachates by Reserve osmosis. Environmental Progress, 2 (4), pp: 251-256.

16. Tanade S, Boki K, Omori Y and Imaki M. (1977). Adsorption of methylsulfide on porous adsorbants (activated carbon, Zeolites and silicats), Tokushima Bunri Daigaku Kiyo, 17, pp: $67-74$.

17. Wang Z.P., Zhang Z., Lin Y.J., Deng N.S., Tao T., Zhuo K., (2002). Landfill leachate treatment by a coagulation-photo oxidation process, J. Hazard. Mater. B95, pp: 153-159.

18. Welander $\mathrm{U}$, Henryson $\mathrm{T}$, Welander $\mathrm{T}$ (1998). Nitrification of landfill leachate using suspended-carrier biofilm technology, Water Res. 31 2351-2355.

19. Yagi M., Kajino M., Matsuo U., Ashitani K., Kita T. and Nakamura T, (1983). Odor problem in Lake Biwa. Water Sci. Technol. 15, 311-321.

\section{How to cite this article:}

Zouaghi, H., M. Ruiti and Ben Thayer, B. 2017. Experimental Study on the Treatment of the Urban Waste Leachates by Oxidation and Adsorption. Int.J.Curr.Microbiol.App.Sci. 6(12): 3921-3936. doi: https://doi.org/10.20546/ijcmas.2017.612.453 